\title{
The use of the microcomputer as an aid in students' understanding of Latin language and literature in a multilingual society
}

\section{J.M. Claassen}

Some knowledge of the Latin terminology of Roman Dutch law is a prerequisite for law students in South African universities. Although there are some points of similarity between black languages and Latin, the differences are such that many students need extra assistance with their study of Latin, which cannot be provided in the normal teaching schedule. The microcomputer is a possible solution to this need, and the author describes a research project in which microsoft QUEST was used to develop drill exercises in vocabulary, accidence and morphology. Student reactions are described.

'n Gedeeltelike kennis van die Latynse terminologie wat in die Romeins-Hollandse reg voorkom, is ' $n$ voorvereiste vir regstudente aan Suid-Afrikaanse universiteite. Alhoewel daar sekere ooreenkomste tussen swart tale en Latyn bestaan, is die verskille van so ' $n$ aard dat heelwat studente ekstra hulp in hul studie van Latyn benodig. Hierdie hulp kan nie deel van die normale onderrigprogram uitmaak nie. Die mikrorekenaar bied 'n moontlike oplossing hiervoor en die skryfster beskryf 'n navorsingsprojek waarin gebruik gemaak is van QUEST om driloefeninge te ontwerp vir woordeskat, morfologie en vormleer. Studentreaksies word beskryf.

Universities in South Africa are faced with the problem of integrating students from widely differing backgrounds into a single intellectual and social community. This community has a unique legal system, introduced when it was still a colony of the Dutch East India Company, which derives from Roman law. To make sense of the Latinate terminology of such a legal system, some command of the language is imperative. Study of the cultural milieu within which the system developed, is a normal concomitant of Latin studies at university level. A statutory minimum of one year post-Matriculation Latin for aspirants to the Bar poses a unique challenge to the Classics Departments of all S.A. Universities, in regard to enrolments and student motivation. This requirement has been reaffirmed by recent judicial and parliamentary action. ${ }^{1}$ Few schools offer Latin, so that the first year at university is spent on a rapidly-paced matriculation-equivalent (beginners') course.

Classicists from other countries often appear envious of the 400-600 enrolments in elementary and first year Latin which South African universities enjoy, but this "enjoyment" is definitely not unalloyed. Many students experience difficulties in learning a highly inflected language and cannot keep up. The element of compulsion is another problem. It 
would appear that students sometimes ascribe the statutory requirement to a dictatorial and diabolical move on the part of the individual Classics Departments to keep up enrolments, and they consequently display considerable emotional resistance.

In the SA multilingual society certain students are further disadvantaged by the fact that compulsory Latin, as a third language, is taught by means of a second language. This applies particularly to non-Indo-European first language speakers, i.e. black students (hereafter "NIEFLS").

It has therefore sometimes been argued that the statutory requirement is a unique tool in the implementation of discrimination, used, as it were, of a linguistic requirement to implement "apartheid". Such an assumption, smacking as it does of arrant intellectual racism, must be rejected out of hand, as it would imply intellectual inferiority in some part of the combined student body at a particular university. It is not the requirement that black students must study Latin that brings problems. The role of Latin as a cultural stimulus and as a bridge between First and Third World cultures is widely acknowledged. ${ }^{2}$ The problem lies at the level of medium of instruction.

Teaching at the major universities is largely in one of the two Europe-based "official" languages, English and the Dutch derivative, Afrikaans, which are also the languages of the South African Bar. As the South African community progressively develops from Third to First World circumstances, there is therefore an increasing challenge to universities to compensate to black students for the fact that instruction is inevitably by means of a second language deriving from a linguistic system that is totally different from their own. Obviously, all students are familiar with the second language, but not all are analytically proficient in its nuances, to such a degree that there will be instant intuitive response to instruction in the sophisticated grammatical exegesis which is a traditional component of Latin teaching. The converse also applies. In South Africa, no classicist is, or can be, proficient in the wide spectrum of home languages represented by his students. ${ }^{3}$

Sentences in English, Afrikaans and Latin, although differing in vocabulary, morphology and superficial syntax, have, as members of the Indo-European language group, a common structural system, which can be explained in terms of similar grammatical concepts. The black languages of Southern Africa are likewise interrelated, but their common language structure differs radically from the IE system. Because of the vast difference in structure and the divergent nature of the IE and black language systems, some Latin students need additional elucidation, preferably in their mother tongue, of the linguistic concepts underlying Latin structural analysis, which forms the basis of the teaching of a so-called "dead language". 4

The only point of contact appears to be that both Latin and the black languages are highly inflected. ${ }^{5}$ There are certain inflective, but also psycho-linguistic, affinities between Latin and black languages. These must be scientifically established and exploited in the development of teaching material. ${ }^{6}$ Points of similarity and contrast between the two inflective systems must be incorporated in the strategies for teaching Latin to black students. Distance-education, for example by means of computer interaction, offers a prime means of coping with this challenge.?

The computer can be used effectively both for drill and for self-paced instruction in the complexities of an inflected language. ${ }^{8}$ It can therefore aid any Latin student towards ultimately understanding a Latin text as communication. ${ }^{9}$ This does not only apply to 
beginners' courses. Some beginners are subsequently stimulated to take up advanced Latin studies, but need additional linguistic help in order to be able to cope adequately with Latin literature at more advanced levels..$^{10}$ For these advanced students, computer programmes can aid in dynamic analysis of lexical, grammatical and structural problems of Latin texts. Computer-based preparation of texts will free time in Latin literature tutorials and seminars for advanced literary analysis and relevant discussion. ${ }^{11}$

The microcomputer as a dynamic medium lends itself ideally to the insertion of a variety of data (i.e. "bridging mechanisms" in different black languages) into extant computer courseware. Use of such courseware will facilitate direct understanding of the Latin passage by a NIEFLS, and, incidentally, improve his command of the modern IE language used as medium of exposition or analysis of the text in question. Ultimately, along with his heightened understanding of the Roman legal system within which he will be operating, his command of the languages he will be employing before the Bar will have been enhanced by his brush with Latin.

Initial research has indicated that general theoretical work on foreign language acquisition, and particularly on FLA for specific professional purposes, offers a wide range of theoretical models, as do papers on computer-based presentation of modern inflected languages. ${ }^{12}$ The array of general literature on computers for academic purposes, and of general software, is considerable, but not all are of equal value. ${ }^{13}$ Literature on Latin courseware is more limited, and descriptive rather than philosophical. ${ }^{14}$

Literature on the problems encountered by NIEFLS in third-language acquisition by means of a second language, and on the interface between the two inflective language systems, is apparently limited to two papers by Wakerley, and theoretical work done by a student at the University of the North under de Vleeschauer ${ }^{15}$. The matter may have been addressed by classicists in the Orient, where yet another language system obtains, but as Latin-for-Law is not compulsory in the various Oriental legal systems, it may not have been considered a serious problem. The field requires thorough exploration, and the present author would welcome correspondence on the subject, particularly from researchers or educators working within a multilingual framework, or, particularly, within two distinct language systems.

The Department of Latin at Stellenbosch University has traditionally been at the forefront of the development of innovative, research-based Latin teaching programmes in South Africa. ${ }^{16}$ The medium of instruction is Afrikaans, but the philosophy of mother-tonguebased instruction is one of its basic tenets. ${ }^{17}$ Its late Chairman, Prof F. Smuts, and his successor, Prof S.M. Bruwer, during 1973-5 completed a research project which led to the establishment of a highly successful, streamlined Lat in beginners' course, with the sentence as syntactical, and therefore also semantic, base of meaningful communication, as its point of departure. This means that the student is from the beginning helped to read Latin literature, and rote learning of paradigms, as prescribed in many "traditional" Latin courses, is seen as secondary to the understanding and interpretation of continuous Latin prose.

Projected continuation of the research and development of suitable computer courseware had subsequently to be relinquished because of the heavy teaching load within the Department. The illness and untimely deaths of both project leaders further delayed projected continuation of the research, but it has since been re-undertaken, and the first project documented, by other members of the Department. ${ }^{18}$ 
In 1987 the author initiated a pilot project for research into the use of the microcomputer in the presentation of Latin literature, with the help of a colleague, Mrs C.A. Malan, and a team of Latin language experts, research assistants and courseware programmers. The experimental courseware developed has already shown itself as highly successful. We are about to launch the second phase of the project, which will address the problems outlined above. Its aims may be formally stated as follows:

1 To conduct research into the interface between two totally different inflective language systems, with a view to the development of multilingual computer-aid for students of Latin literature at South African universities, in the light of, and with particular attention to, problems experienced by non-Indo-European first language speakers (NIEFLS) in compulsory Latin-for-Law courses;

2 To establish means whereby these students will be enabled to comply more effectively with the statutory Latin requirement, while at the same time broadening both their perspectives on the linguistic and cultural background of the legal system within which they as lawyers will operate, and their command of the modern IE languages which are its medium.

The problems to be addressed overlap the fields of social science, linguistics and literary theory, computer implementation and education. Initial research has revealed no other instances of such multilingual courseware as here proposed, nor of extensive linguistic comparison between the two linguistic systems. We have compiled a roster of objectives with the following order of priorities: To continue present research, locally and overseas, into the use of the microcomputer to facilitate students' understanding of Latin literature; to isolate the unique problems of South African beginners, and particularly, of NIEFLS, in compulsory Latin-for-Law courses and to research, adapt or develop, and implement, suitably graded computer courseware to address these problems; to establish areas of significant diversity and also aspects of similarity between the structure of Latin and the structure of the black language system.

Certain overseas-developed Latin computer courseware has been ordered, but slow postal services, and, in some cases, anti-apartheid action have caused delays. ${ }^{19}$ Those examined have proved unsuitable for presentation to students here, because they depend on a different philosophical approach to Latin teaching, or are not compatible with the computer hardware in use at this university. Most appear to treat the language at a very elementary level, and none of those examined so far addresses the problem of understanding consecutive passages of Latin prose.

Correspondence with some overseas researchers has however proved fruitful. Innovative programmes geared to the reading of continuous prose are at present being developed at the Universities of Leeds, England, and Delaware, USA. Their manner of courseware development and formative testing of Latin computer material should offer valuable insights.

Our project breaks new ground, not only in Classical and language studies, but also in the field of the development of student potential in disadvantaged societies. For a broad theoretical basis to be established, research in all these apparently divergent fields is needed. Only after this basic research has been completed shall we be in a position to explore the possibilities of adapting extant computer courseware, our own or other, to the specific needs 
of black students, probably by inclusion of "escape frames" in which elucidation of sentence structures, either by comparison or by analogy, is offered in any of several black languages.

The research team is satisfied that the well-documented and thoroughly tested didactic and linguistic research of the late innovators is adequate as a basis for the Latinate component of the proposed project. During 1987-88 we started developing software. So far the locally developed courseware has appeared most promising. A didactic and remedial programmed lesson framework, subscribing to the Smuts theoretical model of Latin sentence structure ${ }^{20}$, and utilizing the dynamics of PC interaction and the flexibility of colour-screen presentation, was devised, using the computer language TENCORE. Some 24 individual lessons were written and presented for pragmatic evaluation by students.

A series of 3 types of drill exercises based on vocabulary (Latin-Afrikaans-English), accidence (Latin paradigms) and morphology (recognition of forms and remedial corrective feedback), has been devised, using the Microsoft QUEST-interactive testing framework. Some 55 lessons have been completed.

Even in the experimental stage the programme appears to be highly successful. Student response has been positive. No student has been forced to participate in the programme and no attempt has thus far been made to do control-group testing. Formative testing, by observation of individual cases, free response questioning of students and comparison of scoring built into the QUEST system, has indicated the desirability of extending the project. Students report heightened understanding of unfamiliar concepts. Dynamic interaction with the PC, selfpacing, self-timing, and graded programmed presentation fill the often-felt need for individual tutoring which is impossible in a class of 340 students.

Beside the technical team, the researchers are backed by a team of academic advisers from universities throughout the country. ${ }^{21}$ The project is especially suited to be adapted to both the needs of a residential university and the increased demands of "remote education" as current in a large part of a sparsely-populated country such as South Africa. Once the underlying framework of interactive computer courseware has been established and finally edited, the system will lend itself easily to adaptation to the needs of a particular Latin Department at a particular university ${ }^{22}$. It is projected that the final stage will take the form of wider dissemination of the material developed according to the needs and requirements of other Classics Departments or teaching bodies.

A project of this sort cannot be embarked upon in the spirit of mere enquiry. The research plan is rigorously academic but will have, even in its developmental stages, a practical application which will fulfill a stringently-felt need. It is expected that such a system will influence Classical studies throughout the South African context: it will offer a computeraided system for the effective mastery of compulsory Latin by law students in a multilingual society. It will incidentally also aid NIEFLS students in extending their mastery of the modern IE medium of instruction, which also is the medium of the legal world which they will be entering.

\section{Footnotes}

1 HANSARD: Admission of Advocates Amendment Bill. Second reading; RSA 1987: Admission of Advocates Amendment Bill, 54-87 (AS). The SA Bar Council has recently mooted a proposal to eliminate the statutory requirement, but this has not yet received any official sanction. See Claassen 1988a. 
2 BRUWER, S.M. Undated.

3 The five major related language systems of Southern Africa are: Nguni: Zulu, Xhosa, Ndebele, Swazi; Sotho: South Sotho, Tswana, Pedi; Venda-Shangaan; Herero; Wambo. The Khoi-San language system, representing a very small linguistic group, is totally different, and has largely been superseded by the IE "offical languages", as is the case with the native American languages in the USA.

4 WAKERLEY, M.F. 1985.

5 Latin depends on a system of suffix-change, and in somecases, infixing of morphemes. The black language system uses concord of prefixes for nouns with all words structurally related to them, suffix charges for changes of tense, and infixing of morphemes for verbal aspect and mood.

6 WAKERLEY, M.F. 1985

7 BEHR, A.L. 1987.

8 BRUWER, S.M. 1982

9 BRUWER, S.M. 1981.

10 CLAASSEN, J. 1986

11 CULLY, G.R. 1979. SCANLAN, R.T. 1971. SMITH, F 1983(1987). TANG, M.S. 1985 (1987).

12 ROBINSON, B. 1985. VAN CAMPEN, J.A. (1967): "Progress report 1: Project for application of learning theory to problems of second language acquisition with particular reference to Russian." Summarized in unpublished posthumous papers of Prof F. Smuts, Stellenbosch.

13 This is a common problem in a market flooded with software of varying quality. See DAVIES, O. 1982. ATKINSON 1984.

14 CULLEY, C.R. 1979. KERSCHENBAUM, P.E.G. 1986. RUBENSTEIN, 1987. CAIRNS, FRANCIS L. Learning Latin Newsletter. RANDALL, JOHN G., SCANLAN, R.T. undated.

15 Notes 8 \& 9, above; NKATINI, N.L. 1974.

16 e.g.: SMUTS, F. Language acquisition. Unpublished notes taken during research on modern teaching methods, 1968, Ann Arbor Michigan: posthumous papers; SWEET, W.E. undated. SMUTS, F. (1972-1988). SMUTS, F BRUWER S.M. and VAN STEKELENBURG A.V. (1986), VAN STEKELENBURG A.V., BRUWER S.M. and SMUTS, F. (1982-1983) Also see notes 8, 9, 10 above.

17 See, for instance, the series of trilingual teaching texts, note 16 above.

18 CLAASSEN, JO-MARIE (October 1987): Prof S.M. Bruwer \& MALAN, CARINA 1988.

19 Demonstration disks: SCIO (CUNY, Kerschenbaum); Latin Skills (Delaware, Culley); Program: Latin certamen and its extensions (ACL Service Bureau, U Miami, Ohio); Latin flash drill (unspecified provenance, kindly lent by Mr J. Hilton, University of Natal); other letters of enquiry to US firms (New York; VA; Vignola, Italy) have been ignored. 
20 The six types of Latin sentences to be recognized with reference to the character of the verb employed, are: 1) Subject - intransitive verb; 2) Subject - transive verb-object; 3) Subject - copulative: a) used absolutely or with adverbial phrase, b) with noun complement, c) with agreeing adjective; 4) Subject - auxiliary verb - infinitive; 5) Subject - impersonal verb; 6) Subject - passive verb - agent.

21 University of Stellenbosch: Department of Classics, Prof A.V. van Stekelenburg, Dr J.C. Zietsman, Mrs C.A. Malan, Mrs S. Thom.

Bureau for University and Continuing Education: Dr M.M. Malan Chairman, Advisory Committee for CAI: Prof W. Claassen Institute for Language Teaching: Prof Dawid van der Vyver, Dr Jannie Botha Department of Black Languages: Mr Mhlobo Jadezweni University of Cape Town: Department of Classics: Mrs G. Solomons University of Fort Hare: Department of Classics: Mr W. Jennings University of Natal, Durban: Department of Classics: Mr John Hilton, Mrs Anne Gosling

Rhodes University: Department of Classics: Mr Warren Snowball University of Transkei: Emerita from Department of Classics: Prof M.F. Wakerley of Durban

University of the Western Cape: The Teaching Centre: Prof A.J.L. Sinclair University of the Witwatersrand: Centre for Applied Legal Studies: Mr E. Cameron.

22 Lexis Latina offers a basic vocabulary which underlies most universities' beginners' Latin courses and all courses in legal Latin.

\section{Bibliography \& References}

BEHR, A.L. 1987. South African universities today: perceptions for a changing society. South African Journal for Higher Education 1(1), pp 3-10.

BRUWER, S.M. Undated. HSRC research on education: aims with the teaching of Latin in S.A. Unpublished memorandum (in Afrikaans), Department of Latin, Stellenbosch.

BRUWER, S.M. 1981. Memorandum on the use of the computer as teaching aidfor Latin. Unpublished report (in Afrikaans), Department of Latin, Stellenbosch.

BRUWER, S.M. 1982. With the aid of the computer. Paper read at CASA Colloquium Didacticum, UCT, later published in abbreviated form, Akroterion 27 ( 3 \&4) pp 92-3 and 137-43.

CAIRNS, F.L. 1987. Learning Latin Newsletter, nos 1-4, for John \& Randall. Learning Latin: An introductory course for adults. Liverpool, Francis Caims Publ.

CLAASSEN, J. 1987. Interim report on the documentation of research by the late Prof S.M. Bruwer. Unpublished report, Department of Latin, Stellenbosch.

CLAASSEN, J. 1987a. Experiments in the teaching of introductory Latin at university level. South African Journal for Higher Education.

CLAASSEN, J. 1987b. Interim report on the documentation of research by the late Prof S.M. Bruwer. Unpublished report, Department of Latin, Stellenbosch. 
CLAASSEN, J. 1988a. Latin for lawyers - a five year dialogue. South African Law Journal 105, pp 769-776.

CLAASSEN, J. 1988b. Experiments in the teaching of introductory Latin at university level. South African Journal for Higher Education 2.1, pp 35-40.

CULLEY, G.R. 1977. Computer-assisted instruction and Latin beyond flashcards. Classical World 72, p. 393.

DAVIES, G. 1982. Authoring techniques and computer-assisted language learning: How can the teacher make the best use of the microcomputer? Computers in Education: Proceedings of SACCE ' 82 , Stellenbosch

KERSCHENBAUM, P. 1986. 'SCIO' Classical World 79, pp 319-322.

LOCATIS, C.N. \& F.D. Atkinson. 1984. Media and technology for education and training. Columbus, Ohio: Merrill.

MALAN, C.A. 1988. Computer aided instruction as possible solution for problems of firstyear students. (In Afrikaans). Proceedings of Third Annual Conference and Workshop on Excellence in Teaching and Learning in Higher Education, Stellenbosch.

NKATINI, N.L. 1974. 'n Morfosintaktiese taalanalise van die onderwerpsnaamwoordstuk van Afrikaans met Noord-Sotho, Suid-Sotho, Tswana, Tsonga, Shona, Venda, Xhosa en Zulu. Unpublished Honours dissertation from Prof A.J.L. Sinclair, UWC.

ROBINSON, B. 1985. Microcomputers and the language arts. Milton Keynes: Open University Press.

RUBENSTEIN, J.G. 1987. Disco. Classical World 81, pp. 31-32.

SCANLAN, R.T. Undated. A computer-assisted instruction course in vocabulary building through Latin and Greek roots. Undated pamphlet from: Modern Language Annals, pp. 577-583.

SCANLAN, R.T. 1971. Computer-assisted instruction: PLATO in Latin Foreign Language Annals 5, 84-89.

SMITH, F. 1983 (1987). The promise and threat of microcomputers for language learners. Reported in Resources for Education 22.3 (1987) ED. 275138.

SMUTS, F. 1972-1988. Sic venimus Roman: ' $n$ kursus vir Latyn-beginnerstudente. Unpublished teaching course, continually revised and updated. 4 th ed. revised by C.A. Malan and J.C. Zietsman. Stellenbosch.

SWEET, WALDOE. Undated. Construction of pattern practice in an inflected language. Pamphlet of article from unknown source found in posthumous papers of Prof F. Smuts.

SMUTS, F., S.M. Bruwer \& A.V. van Stekelenburg. 1986. Lexis Latina. Pretoria, Academica.

TANG, M.S. 1985 (1987). Microcomputers, software and foreign languages for special purposes and analysis of TXTPRO. Reported in: Resources in Education 21.12. (1986) Ed. 271986. 
VAN STEKELENBURG, A.V., S.M. Bruwer \& F. Smuts. Tria Saecula: Introduction, Test, Notes and Commentaries in 14 volumes: Interval publication, Latin tests with commentary in Afrikaans and English, Department of Latin, Stellenbosch.

WAKERLEY, M.F. 1982. Latin at the University of Transkei. Akroterion 27.3.84,

WAKERLEY M.F. 1985. Law students like Latin - the Unitra Latin Course. Akroterion 30.4. pp 100-103. 